Artikel Penelitian

\title{
Analisis Pelaksanaan Family Development Session Bidang Sanitasi Program Keluarga Harapan di Kecamatan Lengayang
}

\author{
Dona Idola ${ }^{1}$, Hafni Bachtiar ${ }^{2}$, Abdiana $^{2}$
}

\begin{abstract}
Abstrak
Kondisi sanitasi di Pesisir Selatan untuk penduduk dengan akses sanitasi yang layak sebesar 79\% dari jumlah penduduk, ini masih dibawah target SPM Nasional yaitu 85\%. Salah satu upaya untuk mengatasi permasalahan sanitasi adalah dengan Family Development Session (FDS). Tujuan: Menganalisis pelaksanaan FDS bidang sanitasi di Wilayah Kecamatan Lengayang tahun 2018 dengan melihat aspek input (kebijakan, tenaga, biaya, sarana prasarana), proses (perencanaan, pelaksanaan, monitoring dan evaluasi) dan output dari pelaksanaan FDS. Metode: Studi ini menggunakan pendekatan kualitatif, pengumpulan data dilakukan dengan wawancara mendalam, FGD, observasi dan telaah dokumen. Waktu penelitian bulan April sampai Desember 2018 di Wilayah Kabupaten Pesisir Selatan. Informan dalam penelitian ini berjumlah 7 orang dan peserta FGD berjumlah 8 orang untuk setiap nagari. Validasi data dilakukan dengan triangulasi sumber dan metode. Hasil: Kebijakan FDS khusus wilayah Pesisir Selatan sanitasi belum ada, anggaran, sarana dan prasarana tidak mencukupi, tenaga pendamping direkrut dan dilatih langsung oleh Kementrian Sosial, monitoring dan evaluasi FDS sanitasi belum dilakukan secara maksimal baik dari Kabupaten ataupun dari Provinsi. Pada pelaksanaan tenaga pendamping belum sesuai pedoman yang ditetapkan oleh Kementrian Sosial, FDS belum melibatkan lintas sektor seperti puskesmas dan pemerintah nagari. Simpulan: pelaksanaan FDS sanitasi di Kecamatan Lengayang Pesisir Selatan belum berjalan optimal, sehingga perlu peningkatan komitmen dari pendamping untuk benar-benar melaksanakan FDS sesuai petunjuk dan melakukan advokasi ke pemerintah kabupaten agar bisa mengeluarkan kebijakan khusus FDS Sanitasi.
\end{abstract}

Kata kunci: pelaksanaan, sanitasi, FDS, kebijakan

\begin{abstract}
Sanitation condition in Pesisir Selatan for suitable sanitation is $79 \%$ from total amount of population, it still under the target of National SPM 85\%. One of many ways that could be used to overcome sanitation problems is by using Family Development Sessions (FDS). Objectives: To analized the implementation of FDS in sanitation aspect in Lengayang sub district in 2018 according to input, process and output aspect from the implementation of FDS. Methods: This was a qualitative approach, data collection is done by doing deep interview, FGD, observation and research study. This research was done from April until December 2018 in Pesisir Selatan regency. Results: The policy of FDS in sanitation aspect is not yet to be found, the estimation and infrastructure are inadequate, human resource is hired and trained by Social Ministry, the monitored and evaluated FDS in sanitation is not yet to be done maximally whether in regency or province, the FDS in sanitation is not yet to engage with community. In the term of implementation of facilitator is not yet to apply all steps those set by Social Ministry, the implementation is not yet to engage the cross sectors like local government clinic (Puskesmas) and political district administration. Conclusions: the commitment increasing from the facilitator is needed to actually imply FDS prescribed by the regulation, and execute it under the law to the regency government so that it could give particular policy for FDS in sanitation aspect.
\end{abstract}

Keywords: implementation, sanitation, FDS, policy 
Affiliasi penulis: 1. Prodi Magister Kesehatan Masyarakat Fakultas Kedokteran Universitas Andalas Padang (FK Unand),. 2. Bagian IImu Kesehatan Masyarakat FK Unand

Korespondensi: Hafni Bachtiar, Email: hafnibach@gmail.com, Hp : 081277866831

\section{PENDAHULUAN}

Isu global dalam SDG's adalah yang perlu ditangani dalam kurun waktu 15 tahun kedepan adalah kemiskinan. Pemberantasan kemiskinan juga menjadi prioritas utama untuk memenuhi target pembangunan sebuah negara, untuk itu masalah kemiskinan bukan hanya menghambat tapi bila tak segera diselesaikan akan mempengaruhi kondisi ekonomi bahkan sosial pada masyarakatnya.

Angka kemiskinan di Indonesia dalam dua tahun terakhir mengalami penurunan, Menurut Badan Pusat Statistik (BPS) di tahun 2017 angka kemiskinan mencapai $10,12 \%$ atau sekitar 26,58 juta orang dan pada tahun 2018 mengalami penurunan menjadi $9,82 \%$ atau sekitar 25,95 juta orang, penurunan angka kemiskinan ditahun 2018 disebabkan beberapa faktor yaitu inflasi umum sebesar $1,92 \%$ persen rata-rata pengeluaran perkapita tiap bulan untuk rumah tangga 40 persen lapisan terbawah yang tumbuh 3,06 persen, faktor lain adalah bantuan sosial tunai dari pemerintah yang tumbuh $87,6 \%$ pada tahun 2018 dibanding pada tahun 2017 yang hanya tumbuh 3,39\%. Angka kemiskinan di Sumatera Barat pada dua tahun terakhir juga mengalami penurunan, yaitu di tahun 2016 berada pada angka 7,31\% atau sekitar 371,550 ribu orang dan menurun di tahun 2017 menjadi 6,75\% atau sebanyak 364,510 ribu orang. $^{2}$

Berdasarkan penelitian Nurcahya (2015), kondisi kemiskinan akan berdampak negatif pada berbagai aspek, diantaranya aspek kesehatan dan pendidikan. $^{3}$ Keluarga miskin tidak berdaya untuk keluar dari kemiskinan. Keluarga miskin membutuhkan intervensi dari pihak lain untuk bisa keluar dari lingkaran kemiskinan. Dampak lain yang ditimbulkan dari masalah kemiskinan berpengaruh terhadap sanitasi, karena kemiskinan merupakan keadaan dimana masyarakat tidak mampu untuk memenuhi kebutuhan mencukupi fasilitas kesehatan dan sanitasi yang baik, pembangunan bidang sanitasi dapat dibagi menjadi 3 (tiga) bidang yaitu pembangunan bidang pengelolaan sampah, pengelolaan air limbah, dan saluran pembuangan (drainase). ${ }^{4}$

Dalam penelitian Rizki dan Saleh (2017), menjelaskan bahwa pembangunan bidang sanitasi selalu terkendala pada minimnya pendapatan masyarakat sehingga berdampak pada rendahnya kesadaran terhadap pembangunan bidang sanitasi kesehatan. $^{5}$ Fasilitas sanitasi yang higienis sangat penting untuk kesehatan masyarakat. Sejak tahun 1990, jumlah orang yang mendapatkan akses ke sanitasi yang lebih baik telah meningkat dari 54\% menjadi $68 \%$ tetapi sekitar 2,3 miliar orang masih tidak memiliki toilet atau jamban yang lebih baik. Ada 892 juta masih buang air besar di tempat terbuka, misalnya di selokan jalan, di balik semak-semak atau ke perairan terbuka. $^{6}$

Indonesia pada saat ini juga menghadapi masalah di bidang sanitasi dan perilaku hidup bersih dan sehat. Penduduk Indonesia yang hidup dengan kondisi sanitasi buruk mencapai 72.500 .000 jiwa. Mereka tersebar di perkotaan (18,2\%) dan perdesaan (40\%). Kementerian Kesehatan menjelaskan bahwa di Indonesia ada 226 kota yang masih bermasalah dengan pengelolaan air limbah, 240 kota menghadapi masalah pengelolaan sampah, serta 100 kota masih bermasalah dengan drainase. Kota yang bermasalah dengan ketiganya sebanyak 52 kota (Kemenkes RI, 2013). ${ }^{7}$

Program Keluarga Harapan (PKH) di Indonesia dimulai pada tahun 2007 pada 48 kabupaten/ Kota dan mengalami peningkatan sampai tahun 2015 yaitu menjadi 430 kecamatan yang tersebar di 34 Provinsi di Indonesia. Program $\mathrm{PKH}$ di Provinsi Sumatera Barat juga sudah mulai ada sejak tahun 2007, saat itu hanya Kabupaten Pesisir Selatan saja yang mendapat program ini dan untuk Kabupaten Pesisir Selatan Kecamatan Lengayang menjadi salah satu dari 4 (empat) kecamatan angkatan pertama yang mendapatkan Program Keluarga Harapan dengan jumlah KSM $969 .^{8}$

Program Keluarga Harapan (PKH) adalah program pemberian uang tunai kepada Rumah Tangga Sangat Miskin (RTSM) berdasarkan persyaratan dan ketentuan yang telah ditetapkan dengan melaksanakan kewajibannya. Program 
Keluarga Harapan mempunyai strategi yang dikenal dengan Familly Development Session, FDS merupakan proses pembelajaran dan pemberdayaan masyarakat dengan menyampaikan dan membahas informasi praktis dibidang kesehatan, pendidikan, ekonomi dan kesejahteraan keluarga. Penggunaan metode blended learning yaitu memanfaatkan media video animasi, proses diskusi dan dialog antar peserta dan narasumber yang kompeten, maka FDS dirasa mampu menjadi formula demi peningkatan kapasitas diri peserta $\mathrm{PKH}^{9}$

Permasalahan sanitasi yang tidak pernah habisnya membuat Program Keluarga Harapan dari kementerian sosial berupaya menjadikan FDS sebagai salah satu cara untuk melakukan pemicuan dengan harapan dapat menyadarkan masyarakat akan pentingnya peningkatan upaya kesehatan lingkungan, agar terhindar dari penyakit-penyakit berbasis lingkungan. ${ }^{9}$

Berdasarkan Laporan Tahunan Bidang Penyehatan Lingkungan Dinas Kesehatan Provinsi Sumatera Barat Tahun 2016, Kondisi sanitasi di Provinsi Sumatera Barat memang belum menunjukkan angka yang menggembirakan. Selama tahun 20122016 rumah tangga di Sumatera Barat yang mendapatkan kriteria sanitasi dan air minum layak masih berada dibawah $85 \%$ yang menjadi target Standar Pelayanan Minimal (SPM), dimana pada tahun 2012 berada pada angka $44,25 \%$ dan pada tahun 2016 adalah 46,13\%. ${ }^{10}$

Kondisi sanitasi di Kabupaten Pesisir Selatan untuk persentase penduduk dengan akses sanitasi yang layak sebesar $79,9 \%$ dari jumlah penduduk. Penyelenggaraan penyehatan pemukiman difokuskan pada peningkatan rumah sehat. Data yang diperoleh tahun 2015 rumah yang memenuhi syarat kesehatan sebanyak 79.334 unit $(79,8 \%)$. Ini belum mencapai target SPM nasional dengan target pencapaian $85 \% .{ }^{11}$

Salah satu Kecamatan di Kabupaten Pesisir Selatan yang pencapaian target sanitasi atau upaya penyehatan lingkungannya masih rendah adalah Kecamatan Lengayang. Pada tahun 2016 kepemilikan sarana air bersih masih $74,8 \%$, jamban sehat $68,8 \%$, SPAL $64,8 \%$ dan pembuangan sampah $68,8 \%$ dan ditahun 2017 juga masih dibawah target, dimana kepemilikan sarana air bersih masih $75 \%$, jamban sehat $70,4 \%$, SPAL $67,7 \%$ dan pembuangan sampah 69,9\%. ${ }^{11}$ Berdasarkan latar belakang ini, maka penelitian ini bertujuan untuk mengetahui pelaksanaan Family Development Session pada bidang sanitasi di Kecamatan Lengayang.

\section{METODE}

Penelitian ini menggunakan pendekatan kualitatif. Pengumpulan data dilakukan pada bulan April sampai dengan Desember 2018 di Wilayah Kecamatan Lengayang Kabupaten Pesisir Selatan.

Data yang didapatkan berasal dari wawancara mendalam dan Focus Group Discussion (FGD). Informan wawancara mendalam berjumlah sembilan orang yaitu empat orang pendamping $\mathrm{PKH}$, satu orang koordinator $\mathrm{PKH}$, dua orang petugas sanitasi dan dua orang tokoh masyarakat. Informan untuk FGD yaitu delapan orang masyarakat sasaran FDS. Teknik penentuan informan menggunakan metode purposive sampling, selain wawancara mendalam dan FGD, pengumpulan data dilakukan dengan observasi dan telaah dokumen. Analisis data dilakukan dengan metode triagulasi teknik atau metode dan triagulasi sumber. Langkah dalam menganalisis data terdiri dari mereduksi data, menyajikan data, penarikan kesimpulan dan verifikasi.

\section{HASIL}

Berdasarkan wawancara mendalam didapatkan bahwa kebijakan daerah mengenai pelaksanaan FDS termasuk sanitasi tidak ada. Hal tersebut dikarenakan rapat koordinasi PKH tingkat kabupaten belum pernah terlaksana. Pelaksanaan FDS sanitasi lebih mengacu kepada kebijakan yang dikeluarkan oleh kementerian sosial. Beberapa bentuk kebijakan yang dikeluarkan adalah berupa penetapan SK pendamping $\mathrm{PKH}$, didalam SK tersebut juga dijelaskan tanggung jawab dan tugas dari pendamping PKH dalam tugasnya.

Salah satu kewajiban dari pendamping yang tercantum di dalam SK tersebut adalah tentang kewajiban melaksanakan kegiatan FDS termasuk FDS sanitasi, karena selain SK pendamping juga terdapat Permensos No 1 tahun 2108 tentang PKH, sebagai acuan pelaksanaan FDS, serta himbauan menteri sosial yang juga merupakan acuan kebijakan dalam pelaksanaaan kegiatan FDS termasuk FDS sanitasi. 
Berdasarkan hasil wawancara didapatkan bahwa sumber daya manusia sebagai komponen utama pelaksana kegiatan FDS termasuk FDS sanitasi dilakukan oleh tenaga pendamping $\mathrm{PKH}$, perekrutan tenaga pendamping $\mathrm{PKH}$ langsung dilakukan oleh kementerian sosial kemudian tenaga pendamping diberikan diklat khusus FDS termasuk materi tentang FDS sanitasi yang dilaksanakan di BBPPKS Regional I Sumatera di Kota Padang. Pada pelaksanaan diklat FDS pendamping mendapatkan beberapa materi, salah satunya adalah tentang materi sanitasi. Pendamping diajarkan bagaimana melaksanakan kegiatan FDS sesuai dengan ketetapan yang sudah ditentukan oleh kementrian, tidak boleh ada tahapan yang dilewatkan agar materi yang ada dapat diterima dan dipahami oleh masyarakat penerima manfaat PKH sehingga tujuan dari kegiatan FDS dapat tercapai.

Pelaksanaan FDS sanitasi tidak mempunyai anggaran khusus, dana yang disediakan hanya dana dekonsentrasi dari Kementerian Sosial yang disalurkan oleh Dinas Sosial Provinsi kepada pendamping $\mathrm{PKH}$ sebagai pelaksana kegiatan FDS di lapangan sebesar Rp. 2.000.000 untuk 15 orang, tentunya jumlah tersebut tidak mencukupi karena jumlah penerima manfaat per masing-masing pendamping PKH berkisar antara 150- 300 orang.

Berdasarkan hasil wawancara mendalam, sarana dan prasarana yang digunakan saat melakukan FDS sanitasi yaitu beberapa media seperti flipchart, modul, DVD, poster, buku pintar, buku pedoman dengan tujuan meningkatkan pemahaman dan pengetahuan penerima manfaat $\mathrm{PKH}$ terhadap adanya FDS sanitasi. Pendamping kadangkala melakukan FDS di ruang terbuka sehingga semua media tidak bisa di pakai, seperti penggunaan laptop dan proyektor tidak bisa digunakan karena tidak adanya sumber listrik. Pemerintah Daerah Kabupaten Pesisir Selatan belum pernah menganggarkan dana khusus sejak adanya PKH dari tahun 2007 hingga saat ini.

Hasil penelitian juga didapatkan bahwa perencanaan program FDS termasuk FDS sanitasi belum baik. Pendamping sudah membuat RTL, akan tetapi RTL tersebut tidak ada membahas tentang perencanaan dana, sarana dan prasarana. Pelaksanaan FDS sanitasi juga belum maksimal. Hal tersebut karena ada beberapa pendamping yang tidak mengikuti semua tahapan yang ada dalam petunjuk pelaksanaan FDS sanitasi. Pada pertemuan yang diadakanpun tidak mencapai tujuan yang diharapkan karena masyarakat ada yang tidak paham dengan materi yang disampaikan pendamping. Sebagian dari mereka ada yang sudah paham dan mengerti tentang materi sanitasi tapi tidak mempunyai dana untuk membuat WC. Sanksi sudah diterapkan oleh pendamping $\mathrm{PKH}$ di Kecamatan Lengayang bagi peserta yang tidak mengikuti pertemuan FDS termasuk FDS sanitasi akan dikenakan denda Rp. 50.000 untuk satu kali ketidakhadiran dan jika sudah tiga kali tidak mengikuti pertemuan FDS maka akan dikeluarkan dari kepesertaan $\mathrm{PKH}$.

Monitoring dan evaluasi dalam pelaksanaan program FDS sanitasi belum dilakukan maksimal. Hal tersebut karena monev hanya dilakukan saat petugas memberikan laporan, seharusnya monitoring dan evaluasi rutin dilaksanakan minimal satu kali untuk tiga bulan atau enam bulan sekali. Hasil wawancara mendalam juga didapatkan bahwa tokoh masyarakat yang ada di Kecamatan Lengayang tidak pernah dilibatkan dalam kegiatan FDS sanitasi karena selama ini petugas belum pernah berkoordinasi dan mensosialisasikan program FDS sanitasi tersebut di Kecamatan Lengayang tersebut.

Berdasarkan penelitian yang dilakukan dapat diketahui bahwa pelaksanaan FDS sanitasi masih belum maksimal, dikarenakan masih adanya kendala yang dihadapi. Hal tersebut nantinya akan berdampak terhadap pemahaman dan kemauan masyarakat untuk berubah dan meningkatkan sanitasi.

\section{PEMBAHASAN}

\section{Input}

1. Kebijakan

Kebijakan adalah aturan tertulis yang merupakan keputusan formal organisasi yang bersifat mengikat, yang mengatur perilaku dengan tujuan untuk menciptakan tata nilai baru dalam masyarakat. Kebijakan akan menjadi rujukan utama para anggota organisasi atau anggota masyarakat dalam berperilaku. ${ }^{12}$ Pelaksanaan FDS sanitasi di Kabupaten Pesisir Selatan selama ini mengacu pada kebijakan pusat diantaranya SK pendamping $\mathrm{PKH}$, permensos 
No 1 Tahun 2018 tentang PKH serta surat himbauan Menteri Sosial nomor 202/MS/C/12/2018 dan belum ada kebijakan khusus yang dibentuk untuk pelaksanaan $\mathrm{PKH}$ di Daerah Pesisir Selatan. ${ }^{13}$

Berbeda dengan penelitian Ervita (2017) bahwa kebijakan pelaksanaan program $\mathrm{PKH}$ bidang kesehatan di Kota Padang berpedoman kepada kebijakan yang dikeluarkan Kementerian Sosial dan Kementerian Kesehatan, diperkuat juga dengan adanya Surat Keputusan Walikota Padang. ${ }^{14}$

Semua kebijakan yang menjadi landasan pelaksanaan FDS Sanitasi di Pesisir Selatan mestinya dapat disosialisasikan kepada semua lintas sektor yang terlibat dalam pelaksanaan FDS, sehingga sama-sama memahami apa yang menjadi tujuan pelaksanaan FDS dan memahami apa yang menjadi tugas dan bagian masing-masing lintas sektor dalam pelaksanaan FDS tersebut dan pelaksanaan sosialiasi semestinya dilakukan oleh Koordinator Kabupaten PKH Pesisir Selatan.

Berdasarkan Permensos No 1 tahun 2018 tentang Program Keluarga Harapan terdapat kebijakan yang mengatur tentang koordinasi yang harus dilaksanakan oleh daerah. Turunan dari Permensos No 1 Tahun 2018 tersebut berupa himbauan Menteri Sosial Nomor 202/MS/c/2018 tentang Dukungan Dana Daerah penyertaan dana $\mathrm{PKH}$ minimal 5\%. Dalam surat himbauan menteri sosial tersebut terdapat himbauan kepada kepala daerah yang kabupaten/Kotanya menerima bantuan $\mathrm{PKH}$ agar menyediakan dana Sharing sebesar 5\% untuk kelancaran pelaksanaan $\mathrm{PKH}$ didaerah, salah satunya untuk kelancaran kegiatan FDS ini khususnya FDS sanitasi. ${ }^{13}$

Diharapkan adanya rapat koordinasi tingkat kabupaten yang membahas kebijakan mengenai FDS, sehingga semua lintas sektor terkait mengetahui akan tugas dan fungsinya masing-masing. Sehingga tidak adalagi yang tidak tahu kegiatan FDS sanitasi yang dilakukan pendamping $\mathrm{PKH}$.

\section{Sumber Daya Manusia}

SDM atau tenaga merupakan komponen yang sangat penting dalam menggerakkan keseluruhan fungsi manajemen yang ada. Pelaksanaan suatu kebijakan tidak akan berhasil jika tidak didukung oleh sumber daya manusia yang cukup baik secara kualitas maupun secara kuantitas. ${ }^{15}$

Sumber daya manusia adalah orang-orang yang terlibat langsung dalam program FDS sanitasi. Dalam hal ini SDM yang terlibat langsung adalah pendamping wilayah. Pendamping SDM sebagai sumber daya yang sangat berperan penting dalam penyampaian informasi kepada masyarakat sangat mempengaruhi efisiensi pelaksanaan kegiatan FDS. Penelitian yang dilakukan oleh Nurcahya (2015) bahwa aspek kemampuan pendidik dalam hal ini fasilitator berpengaruh terhadap efisisiensi capaian program, semakin baik kemampuan pendamping maka semakin tinggi kemungkinan informasi yang disampaikan bisa diterima dan dipahami masyarakat. ${ }^{3}$

Latar belakang pendidikan, pelatihan dan kualitas telah mencukupi dan memadai kualifikasi dari pendamping $\mathrm{PKH}$ yang ditentukan oleh kementerian sosial saat perekrutan. Pendamping PKH merupakan tenaga yang direkrut langsung oleh Kemensos RI melalui Dinas Sosial Kab/Kota. Jumlah pendamping $\mathrm{PKH}$ disesuaikan dengan jumlah penerima manfaat $\mathrm{PKH}$ yang terdaftar di masing masing kecamatan, topografi wilayah juga mempengaruhi kuantitas pendamping ini.

Berdasarkan fakta yang ditemukan dilapangan yang menjadi pendamping untuk memberikan materi FDS sanitasi berasal dari berbagai macam latar belakang pendidikan, sehingga ini menjadi satu kendala bagi pendamping dalam menyampaikan informasi tentang materi sanitasi walaupun pendamping telah mengikuti diklat. Penyegaran secara berkala harus dilakukan kepada pendamping PKH sebagai pelaksana dari kegiatan FDS sanitasi dengan cara memberikan pelatihan mengenai FDS sanitasi ini secara kontinyu.

Permasalahan tersebut semestinya dapat diatasi dengan melakukan pembinaan ulang kepada pendamping, walaupun pendamping telah mengikuti diklat. Koordinator kabupaten sebagai penanggung jawab seharusnya selalu mengevaluasi tingkat pemahaman pendamping FDS terhadap materi sanitasi sehingga jika memang hasil evaluasi kemampuan pendamping dinilai rendah. 


\section{Anggaran Biaya}

Biaya merupakan salah satu faktor penentu terlaksananya suatu kegiatan, sebab dengan adanya dukungan anggaran yang memadai dapat membantu kegiatan berjalan secara efektif.

Kegiatan FDS tidak mempunyai anggaran khusus karena kegiatan FDS dilakukan bersamaan dengan kegiatan pokok PKH yaitu pertemuan kelompok yang wajib dilakukan pendamping minimal satu bulan sekali. Penelitian yang dilakukan Ervita (2016) juga mendapatkan biaya pelaksanaan kegiatan PKH bidang kesehatan yang digunakan adalah biaya yang ada dari APBN dan kegiatan PKH bidang kesehatan menyatu dengan kegiatan PKH lainnya. ${ }^{14}$

Menurut Permensos No 1 Tahun 2018 biaya bantuan PKH bidang kesehatan berasal dari APBN melalui DIPA Dikretorat Jaminan Sosial, Dikretorat Jenderal Perlindungan dan Jaminan Sosial, Kementerian Sosial RI. Anggaran tersebut terdiri dari bantuan tunai bersyarat kepada peserta $\mathrm{PKH}$ dan kegiatan penunjang (Sumber Daya Manusia, Kelembagaan, Monitoring dan Evaluasi serta kegiatan penunjang lainnya). ${ }^{13}$

Berdasarkan hasil penelitian diketahui bahwa pembiayaan program FDS mendapatkan bantuan dana dekonsentrasi dari Kementerian Sosial, dalam hal ini disalurkan oleh Dinas Sosial Provinsi Sumatera Barat sebesar Rp 1.000.000 sampai Rp 2.000.000 untuk masing-masing pendamping. Jumlah tersebut berbeda setiap tahunnya tegantung kepada anggaran yang dicairkan oleh Kementerian Sosial kepada Dinas Sosial Provinsi Sumatera Barat. Kebijakan diambil oleh Dinas Sosial Provinsi Sumatera Barat bahwa dana dekonsentrasi tersebut digunakan untuk menunjang kegiatan FDS termasuk FDS sanitasi di lapangan.

Kebijakan penggunaan dana dekonsentras tersebut digunakan untuk transportasi yang mengakomodir transportasi, snack dan makan siang untuk 15 orang penerima manfaat saja. Jumlah in tentu tidak mencukupi karena, rata-rata masyarakat penerima manfaat $\mathrm{PKH}$ untuk masing-masing pendamping bervariasi, dengan jumlah lebih kurang 150 sampai 300 orang, sehingga selama ini dengan uang $\mathrm{Rp} 2.000 .000$ tersebut, pendamping hanya menyediakan konsumsi untuk pelaksanaan kegiatan dengan tujuan semua sasaran dapat merasakannya.

Dinas Sosial Provinsi Sumatera Barat seharusnya tidak mengambil kebijakan dengan membagikan dana dekonsentrasi ini hanya untuk 15 orang penerima manfaat. Hal ini akan menjadi sebuah ketimpangan dan kecemburuan terhadap penerima manfaat lainnya. Sebaiknya mengalihkan penggunaan dana dekonsentrasi tersebut untuk kegiatan penunjang kegiatan FDS termasuk FDS sanitasi. Penggunaan tersebut misalnya dengan cara menggunakan dan dekonsentrasi tersebut untuk menggandakan buku pintar bagi pendamping yang masyarakat sasarannya belum semua mendapatkan buku pintar yang diberikan oleh kementerian sosial.

\section{Sarana dan Prasarana}

Sarana dan prasarana termasuk material dalam masukan (input) suatu organisasi. Sarana merupakan alat bantu untuk memperlancar dan mempermudah pekerjaan. ${ }^{16}$

Media yang dimiliki oleh pendamping hanya berupa flipchart, poster, DVD, buku pintar dan modul kesehatan. Dari media tersebut hanya flipchart yang sering dimanfaatkan. Berbeda dengan penelitian Ervita (2017) kurangnya sarana berupa leaflet, flipchart dan poster sangat mempengaruhi upaya promosi yang dilakukan ke masyarakat padahal alat peraga atau media promosi sebenarnya sangat membantu untuk meningkatkan pengetahuan masyarakat mengubah prilaku ke arah positif. ${ }^{14}$

Dalam penelitian ini yang menjadi kendala saat penyampaian materi FDS sanitasi adalah kurangnya sarana dan prasarana diantaranya, tidak semua peserta FDS sanitasi mendapatkan buku pintar karena keterbatasan pembagian dari kementerian sosial. Pemutaran film pada beberapa kelompok FDS sanitasi tidak dapat dilakukan karena tidak adanya sumber listrik untuk pemutaran film tersebut. Ada kalanya pertemuan FDS dilakukan di lapangan terbuka yang tidak mempunyai sumber listrik, selain itu ada juga pendamping $\mathrm{PKH}$ yang tidak mempunyai laptop sehingga tidak bisa menampilkan film tentang FDS sanitasi tersebut. 
Hal ini membuat penyampaian informasi menjadi terbatas dan mempengaruhi hasil yang dilharapkan, sehingga peserta menjadi kurang tertarik untuk mengikuti materi secara serius. Ada juga yang kurang menyimak saat pendamping memberikan materi FDS termasuk FDS sanitasi, hal ini juga mempengaruhi kurangnya pengetahuan dan kesadaran masyarakat untuk mau berubah guna meningkatkan kehidupan yang bersih dan sehat.

Menurut standar yang ditetapkan Kementerian Sosial, alat-alat yang harus dimiliki adalah adalah modul bagi pendamping, buku pintar, brosur, poster, flipchart, film, alat permainan (kartu, papan permainan). peralatan audio visual pendukung berupa laptop, speaker, TV, DVD player dan alat tulis. Seluruh media yang ada mestinya benar-benar tersedia serta dapat dipakai dan dimanfaatkan oleh pendamping dalam penyampaian informasi seputaran FDS termasuk FDS sanitasi. ${ }^{17}$

\section{Proses}

\section{Perencanaan}

Fungsi perencanaan yaitu kegiatan bersama untuk menentukan tujuan-tujuan umum dan khusus suatu program. Perencanaan FDS sanitasi di Kabupaten Pesisir Selatan belum baik, karena dalam perencanaan tersebut pendamping $\mathrm{PKH}$ tidak membuat perencanaan menganai pengunaan dana, sarana dan prasarana yang dibutuhkan untuk menunjang kegiatan FDS sanitasi.

Perencanaan dilakukan oleh pendamping saat berada di balai diklat yang diadakan oleh Kementerian Sosial. Saat mulai turun ke Kabupaten, koordinator kabupaten juga harus mengetahui apa saja perencanaan dari masing-masing pendamping. Hanya saja dalam perencanaan yang dibuat pendamping belum mencantumkan kegiatan monitoring dan evaluasi yang harusnya juga dilakukan oleh koordinator kabupaten dan provinsi. Hal ini berguna untuk melihat apakah semua kegiatan FDS yang direncanakan sudah benar-benar terlaksana seluruhnya, jika memang belum berjalan sesuai rencana mestinya dicari penyebab dan solusinya.

\section{Pelaksanaan}

Family Development Session merupakan program pengembangan dari $\mathrm{PKH}$ yang diharapkan dapat membantu pendamping $\mathrm{PKH}$ meningkatkan kapasitas diri dan mengubah pola hidup keluarga yang miskin menjadi keluarga yang mapan. Program FDS ini adalah pemberdayaan masyarakat melalui proses pembelajaran. Proses pembelajaran memang seringkali berlangsung lambat, tetapi perubahan yang terjadi akan bertahan lama. Proses belajar dalam pemberdayaan bukanlah proses "menggurui", melainkan menumbuhkan semangat belajar bersama yang mandiri dan partisipatif. ${ }^{9}$

Berdasarkan penelitian yang dilakukan, kegiatan FDS sanitasi sudah dilaksanakan di semua wilayah dampingan pendamping $\mathrm{PKH}$ di Kecamatan Lengayang dengan jumlah peserta 998 orang peserta. Ada juga didapatkan informasi dari FGD mengenai adanya pertemuan penyampaian materi FDS sanitasi di Kecamatan Lengayang, setelah melakukan kegiatan FDS sanitasi, pendamping akan mengirim laporan yang didalamnya terdapat absensi kehadiran peserta.

Hasil observasi diketahui bahwa masih ada pendamping yang meninggalkan atau tidak menyampaikan seluruh materi yang ditetapkan dalam petunjuk, waktu penyampaian juga tidak sesuai dengan standar waktu yang ditetapkan pada langkahlangkah diatas, pendamping menyampaikan lebih cepat dari waktu yang ditetapkan tersebut, sehingga informasi yang dilaksanakan pada saat FDS sanitasi tidak sampai kepada masyarakat secara maksimal, bahkan setelah dilakukan wawancara dengan peserta FDS sanitasi banyak yang tidak mengetahui materi apa yang mereka terima dari FDS sanitasi. Hal ini seharusnya menjadi perhatian dari Koordinator penanggung jawab wilayah dan melakukan evaluasi terhadap kinerja pendamping wilayah, untuk mengoptimalkan pelaksanaan FDS sanitasi di Pesisir Selatan.

Pendamping $\mathrm{PKH}$ perlu melakukan pengawasan secara rutin kepada penerima manfaat $\mathrm{PKH}$ di wilayah kerja mereka masing-masing, untuk memantau perkembangan peningkatan pengetahuan 
dan kesadaran diri dari peserta FDS sanitasi untuk berperilaku hidup bersih dan sehat sesuai dengan materi FDS yang telah diberikan. Pemantauan hendaknya dilakukan pendamping $\mathrm{PKH}$ langsung ke rumah penerima manfaat $\mathrm{PKH}$ agar mereka merasa mendapat perhatian dari pendamping mereka untuk perubahan perilaku menjadi lebih sehat.

\section{Monitoring dan Evaluasi}

Monitoring merupakan suatu proses pemantauan yang dilakukan untuk melihat hasil kerja dari suatu kegiatan, sedangkan evaluasi dalam fungsi manajemen, merupakan fungsi penilaian. $^{18}$ Dalam pelaksanaan FDS sanitasi di Kabupaten Pesisir Selatan selama ini monitoring dan evaluasi belum dijalankan

Menurut pedoman dari pelaksanaan FDS monitoring dilakukan rutin setiap bulannya untuk melihat sejauh mana program yang dilaksanakan oleh pendamping kepada masyarakat penerima manfaat PKH. ${ }^{17}$ Monitoring dilakukan oleh Penanggung Jawab PKH Kabupaten, seharusnya juga dilakukan minimal sekali setahun melalui rapat koordinasi tingkat kabupaten yang harus dilaksanakan oleh pemerintah daerah Kabupaten Pesisir Selatan.

Permensos No 1 Tahun 2018 pemantauan dan monitoring di tingkat Kabupaten dilakukan oleh bupati, dan di tingkat provinsi dilakukan oleh gubernur, sedangkan untuk tingkat pusat yang melakukan pemantauan dan evaluasi adalah menteri. ${ }^{13}$ Pada tingkat Kabupaten Pesisir Selatan hal ini belum dijalankan. Pimpinan Daerah diharapkan bisa melakukan pemantauan dan evaluasi secara rutin minimal satu kali setahun sesuai peraturan perundang-undangan yang berlaku.

\section{Dukungan Tokoh Masyarakat}

Berdasarkan hasil penelitian didapatkan bahwa tokoh masyarakat yang ada di Kecamatan Lengayang tidak pernah dilibatkan dalam kegiatan FDS sanitasi. Hal tersebut dikarenakan petugas belum pernah melakukan koordinasi dan sosialisasi mengenai program FDS sanitasi tersebut di Kecamatan Lengayang.

Keberadaan tokoh masyarakat sangat berpengaruh terhadap masyarakat, kesusksesan suatu program kemasyarakatan biasanya disebabkan oleh peran serta dari tokoh masyarakat yang ada di daerah tersebut. Hal tersebut disebabkan karena masyarakat masih menghargai orang-orang yang dianggap sebagai pemuka masyarakat dan akan selalu mereka jadikan panutan tdan ikuti. Tokoh masyarakat dianggap penting karena mampu menjembatani program atau kegiatan kemasyarakatan dimana tokoh masyarakat memiliki kedekatan secara emosional dengan masyarakat setempat. ${ }^{19}$

Pendamping $\mathrm{PKH}$ juga wajib melakukan kerjasama atau koordinasi dengan tokoh masyarakat yang ada di lingkungan masyarakat khususnya di Kecamatan Lengayang. Keterlibatan tokoh masyarakat sangat diperlukan dalam pelaksanaan program FDS sanitasi di Kabupaten Pesisir Selatan yang dapat memberi motivasi dan arahan pada masyarakat sehingga FDS dapat terlaksana dengan baik.

\section{Output}

Keluaran yang diharapkan dari pelaksanaan FDS ini adalah terlaksananya FDS sanitasi Program Keluarga Harapan di Kecamatan Lengayang Kab Pesisir Selatan secara optimal. Berdasarkan hasil penelitian diketahui bahwa FDS sudah terlaksana, namun masih ada kendala yang dihadapi dalam pelaksanaannya sehingga hasil yang dicapai belum optimal.

Kendala yang ditemukan yaitu kurangnya anggaran dana dalam pelaksanaan FDS. Azwar (2010) menyebutkan bahwa sumber biaya kesehatan terbagi 2 (dua); yang pertama seluruhnya bersumber dari anggaran pemerintah, dan yang kedua sebagian ditanggung oleh masyarakat. ${ }^{16}$ Berdasarkan Permensos No 1 Tahun 2018 biaya bantuan PKH bidang kesehatan berasal dari APBN, namun anggaran khusus untuk pelaksanaan FDS tidak ada. ${ }^{13}$

Kekurangan lain dalam pelaksanaan FDS ini yaitu adanya pendamping yang tidak melaksanakan proses sesuai alur serta kurang sarana prasarana. Hal tersebut menunjukkan bahwa program FDS sanitasi di wilayah Kecamatan Lengayang belum berjalan dengan optimal. Penguatan komitmen dari Pemerintah Kabupaten Pesisisr Selatan terhadap adanya pelaksanaan program FDS sanitasi, disamping 
itu komitmen yang kuat dari pendamping untuk dapat melaksanakan FDS sanitasi sesuai yang ditetapkan oleh Kementerian Sosial.

\section{SIMPULAN}

Pelaksanaan FDS sanitasi di wilayah Kecamatan Lengayang belum berjalan dengan optimal dikarenakan masih adanya beberapa kendala. Kendala yang dihadapi seperti masih ada pendamping yang tidak melaksanaan proses sesuai alur atau aturan yang ada, tidak adanya dana khusus untuk FDS, kurang sarana prasarana dan tidak adanya kegiatan monitoring evaluasi dari Kabupaten atau pemerintah daerah serta belum adanya komitmen yang kuat dari pemerintah daerah Kabupaten Pesisir Selatan untuk pelaksanaan PKH selama ini.

\section{SARAN}

Disarankan kepada koordinator kabupaten agar melakukan advokasi kepada Pemerintah daerah kabupaten untuk segera melakukan rapat koordinasi tingkat kabupaten untuk membahas kegiatan FDS sanitasi agar dapat berjalan lebih baik, melakukan monitoring setiap bulannya dan evaluasi minimal satu kali dalam satu tahun. Tenaga sanitasi di puskesmas dan dinas kesehatan diharapkan melakukan kerjasama dengan pendamping $\mathrm{PKH}$ untuk melakukan kegiatan pemicuan bersama-sama sehingga tujuan peningkatan capaian cakupan sanitasi di Kabupaten Pesisir Selatan dapat meningkat.

\section{UCAPAN TERIMA KASIH}

Terima kasih kami sampaikan kepada Dinas Sosial Kabupaten Pesisir Selatan yang telah memberikan pengetahuan yang sangat bermanfaat bagi penulis dan semua informan yang telah bersedia memberikan informasi terkait penelitian ini. Terima kasih juga kepada pihak lain yang turut membantu dalam menyelesaikan penelitian ini.

\section{DAFTAR PUSTAKA}

1. Nayata EJ. Pemberdayaan keluarga penerima manfaat melalui program keluarga harapan di Kelurahan Kelun Kecamatan Kantoharjo Kota Madiun. Jurnal Sosiologi DILEMA. 2017;32(2):1-9.
2. Badan Pusat Statistik (BPS). Angka kemiskinan di Indonesia. Jakarta: BPS; 2017.hlm.51-3.

3. Nurcahya F. Evaluasi program family development session di desa Kebunden Lor, Prambanan, Klaten (studi survei di unit pelaksana program keluarga harapan Kecamatan Prambanan). Jurnal Student Universitas Negeri Yogyakarta. 2015;4(3):5-8.

4. Soeranto DA. Kualitas manusia Indonesia dan pembangunan prasarana sanitasi. Jakarta: Media Persik; 2004.hlm.28-36.

5. Rizki B, Saleh. Keterkaitan Akses Sanitasi dan Tingkat Kemiskinan Studi kasus di Propinsi Jawa Tengah. Jurnal Ekonomi Pembangunan. 2017;12 (3):221-33

6. Kementerian Kesehatan Republik Indonesia (Kemenkes RI). Pusat data dan informasi. Jakarta: Kemenkes RI; 2017.

7. Kementerian Kesehatan Republik Indonesia (Kemenkes RI). Profil Kesehatan. Jakarta: Kemenkes RI; 2013.

8. Kementerian Sosial Republik Indonesia (Kemensos RI). Kebijakan FDS dalam program keluarga harapan Sumatera Barat. Jakarta: Direktorat Jaminan Sosial RI; 2015.

9. Kementerian Sosial Republik Indonesia (Kemensos RI). Materi pelatihan bagi pendamping bidang kesehatan. Jakarta: Pusat Pelatihan dan Pendidikan Kementerian Sosial Republik Indonesia. 2017;34-61.

10. Dinas Kesehatan (Dinkes) Provinsi Sumatera Barat. Profil kesehatan Provinsi Sumatera Barat tahun 2016. Padang: Dinkes Provinsi Sumatera Barat; 2017.

11. Dinas Kesehatan (Dinkes) Kabupaten Pesisir Selatan. Laporan tahunan Dinkes Kabupaten Pesisir Selatan. Pesisir Selatan: Dinkes Kabupaten Pesisir Selatan; 2017.

12. Subarsono A. Analisis kebijakan publik (konsep, teori, dan aplikasi). Yogyakarta: Pustaka Pelajar; 2011.hlm.30-1.

13. Peraturan Menteri Sosial Republik Indonesia nomor 1 tahun 2018 tentang program keluarga harapan. Jakarta; 2018.

14. Ervita D. Analisis implementasi program harapan $(\mathrm{PKH})$ bidang kesehatan di Kecamatan Koto Tangah Kota Padang tahun 2016 [tesis]. Padang: 
Universitas Andalas. 2017.hlm.22-56.

15. Hasibuan SP. Manajemen sumber daya manusia. Edisi Revisi. Jakarta: Bumi Aksara; 2005.hlm.29.

16. Azwar A. Pengantar administrai kesehatan. Jakarta: Binarupa Aksara; 2010.hlm.43-67.

17. Kementerian Sosial Republik Indonesia (Kemensos RI). Pedoman pelaksanaan diklat P2K2/FDS PKH E-Learning tahun 2019. Jakarta:
Pusat Pendidikan dan Pelatihan Kesejahteraan Sosial; 2019.

18. Adisasmito W. Sistem kesehatan. Jakarta: Rajawali Pers; 2014. 54.

19. Mubarak, lqbal W, Chayatin N. Ilmu kesehatan masyarakat teori dan aplikasi. Jakarta: Salemba Medika; 2009.hlm.39-41. 